\title{
Godsdienspluraliteit en die liberale staat - die illusie van sekulêre neutraliteit
}

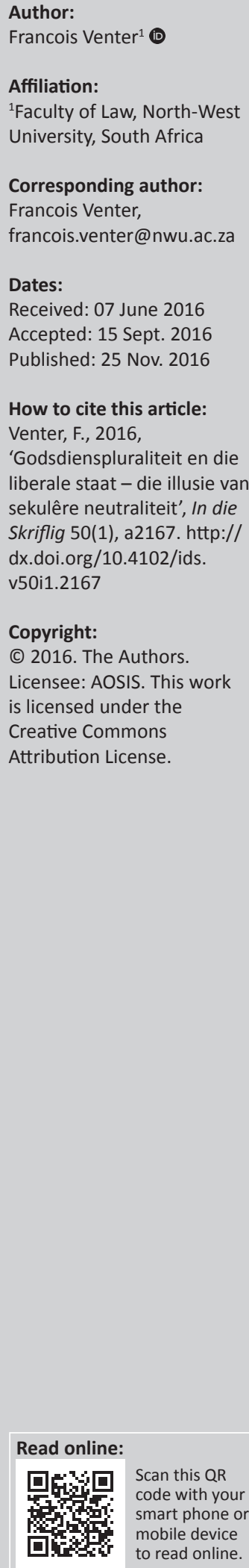

\begin{abstract}
Religious pluralism and the liberal state - the illusion of secular neutrality. Whereas church and state have long been separated since the emergence of the modern state, law and religion have not been separated and can never be separated. The notion of the liberal-democratic state, which is still dominant in legal thinking, induces state authorities to seek refuge in secular neutrality when confronted with religious issues to be resolved by law and judicial resolution. This article sketches the constitutional background, the undeniable relationship between law and religion, the standard liberal response to resulting difficulties and the dawn of a post-secular era. Examples are discussed from German, Canadian and South African jurisprudence that dealt with religious issues, leading to an assessment of the viability of secular neutrality. It is found that neutrality is unachievable. A suggestion is made that objective reciprocity founded on the teachings of Jesus and accepted as a universal human norm, independently of Christian teachings, may present an appropriate approach to avoid the dilemmas brought about by secularism. The implication of this analysis is that some firm arguments based on biblical justification have universal persuasive power, because they appeal to universal values also acceptable to non-believers and other religions. These arguments may be used in courts and by other organs of state for the resolution of religious matters that have legal implications in the pluralistic society of the 21st century.
\end{abstract}

\section{Inleiding}

Die proses van Suid-Afrika se grondwetskrywing het in 1993 en 1996 'n grondwet opgelewer wat wye erkenning as 'n liberaal-demokratiese model geniet. Die uitkoms is op sigself buitengewoon in die lig daarvan dat die voorkeure van die opponerende onderhandelingspartye nie in die liberalisme gewortel was nie (sien Venter 2010:43-63). Die Grondwet van 1996¹ (Republiek van Suid-Afrika 1996) maak ruim voorsiening vir die hantering van kulturele en godsdienspluraliteit. Die betrokke bepalings kan vergelyk word met soortgelyke bepalings in ewekniegrondwette soos dié van Kanada en Duitsland, maar kan ook duidelik daarvan onderskei word. Ook duidelik anders as sy voorgangers, gee die Grondwet nie eksplisiet erkenning aan die soewereiniteit van God nie. ${ }^{2}$

Hoe die staat ingevolge 'n grondwet met 'n liberaal-demokratiese strekking behoort om te gaan met religieuse aangeleenthede, godsdiensdiversiteit en sekularisme is ' $n$ brandende kwessie in die geglobaliseerde wêreld van die een-en-twintigste eeu. Sekulêre neutraliteit is die instinktiewe liberale respons in hierdie verband, maar nadere ondersoek maak dit duidelik dat dit 'n onwerkbare illusie is. Hieronder word die problematiek verbonde aan staatsneutraliteit toegelig aan die hand van regspraak waar godsdienskwessies ter sprake was. Ten slotte word die rigting waarin die oplossing gevind mag word, toegelig.

\section{Toepaslike grondwetlike bepalings}

Baie grondwette, veral in die Westerse wêreld, maak in hulle voorredes en bepalings melding van God. Die vertolking en toepassing van sodanige vermeldings varieer, hoewel daar' $n$ sterk tendens is om sulke bepalings van godsdienstige konnotasies te stroop deur daarna as 'ceremonial deism' te verwys. $^{3}$

Die voorrede van die Grondwet word afgesluit met die titelwoorde van die nasionale lied ('nkosi Sikelel' iAfrika') in vier tale. Die Afrikaans lui: 'Mag God ons mense beskerm' en 'God seën Suid-Afrika' 1.Voortaan 'die Grondwet'.

2.Die aanhef van die 1993 Grondwet het, soos sy voorgangers, met hierdie woorde begin: 'In nederige erkentlikheid teenoor die Almagtige God ...' (Republiek van Suid-Afrika 1993).

3.Sien byvoorbeeld die Amerikaanse Supreme Court se uitspraak in Lynch, Mayor of Pawtucket, et al. v Donnelly et al. (United States of America 1984), wat deur die Suid-Afrikaanse Konstitusionele Hof nagevolg is in In re: Certification of the Constitution of the Western Cape (Republic of South Africa 1997a). 
(Republiek van Suid-Afrika 1996). ${ }^{4}$ Die voorskrifte vir ampsede bied aan die eedafleggers die keuse om 'n plegtige verklaring of ' $n$ eed af te lê. Laasgenoemde word bevestig met die woorde: 'So help my God' (Republiek van SuidAfrika 1996: bylae 2).

Verskeie bepalings vermeld godsdiens: artikel 6(5)(b)(ii) wat aan die Pan-Suid-Afrikaanse Taalraad die verpligting oplê om respek te bevorder en te verseker vir tale wat in Suid-Afrika vir godsdiensdoeleindes gebruik word; artikel 9(3), wat 'onbillike' diskriminasie op grond van onder meer godsdiens, gewete en oortuiging verbied; artikel 15, wat vryheid van godsdiens, oortuiging en mening as 'n fundamentele reg beskerm; artikel 16(2)(c), wat haatspraak, onder meer op godsdiens gerig, verbied; artikel 31, wat die oprigting en lidmaatskap van'n godsdiensgemeenskap en gemeenskaplike deelname aan godsdiensbeoefening as 'n fundamentele reg beskerm; artikel 35(2)(f)(iii), wat aan aangehoudenes en gevangenes die reg gee om in verbinding te tree met en besoek te word deur 'n godsdiensraadgewer van hulle eie keuse; en artikel 185, wat voorsiening maak vir die instelling van die Kommissie vir die Bevordering en Beskerming van die Regte van Kultuur-, Godsdiens- en Taalgemeenskappe.

Uit hierdie bepalings is dit duidelik dat die Grondwet geformuleer is om uitgebreide regsbeskerming vir godsdienspluraliteit, groeps-enindividuelegodsdiensvryheid te verseker en om onderlinge godsdiensverdraagsaamheid te bevorder. Dit is net so belangrik om te besef dat die Grondwet geen eksplisiete voorsiening vir staatsvoorkeur of -bevoordeling van enige godsdiens of religieuse instelling maak nie.

\section{Die verband tussen godsdiens en reg}

Die geskiedenis van moderne staatskap wat onbetwisbaar deur die geskiedenis van die Noord-Atlantiese lande gedomineer word, is nou verweef met die proses van skeiding tussen kerklike en staatlike gesag. Allerweë word die Vredesverdrag van Wesfale (1648), wat die bloedige 30-jarige oorlog tussen die Katolieke en Protestante beëindig het, as die geboortedatum van die moderne staat beskou. Op grond daarvan dat daar in Wesfale ooreengekom is om die beginsel van cuius regio, eius religio te herbevestig, kan selfs gesê word dat godsdiensvryheid die eerste mensereg is wat erkenning ontvang het.

Teen hierdie agtergrond moet die verband en interafhanklikheid van godsdiens en reg tot in die een-en-twintigste eeu gesien word. Dit is die produk van eeue-lange filosofiese, morele en taalontwikkelinge waardeur godsdiens en reg kenmerke geword het van die menslike samelewing, en wel as onontbeerlike instellings daarvan. Die verband tussen die twee sfere blyk ook uit ooreenkomste soos dat albei oor opvattings en persepsies van gesag en orde in die lewe van mense as individue en gemeenskappe handel.

4.Die Engelse teks van die Grondwet is die enigste amptelike weergawe. Die teks wa hier gebruik word, is 'n goeie nie-amptelike Afrikaanse vertaling.
Net so belangrik soos die ooreenkomste, is die verskille tussen godsdiens en reg. Die geskiedenis leer ons duidelik dat waar kerklike gesag oor die staat heers, of andersom, spanning, onreg en gevolglik dikwels oproer en geweld daaruit spruit. Juridiese onderdrukking van godsdiens of geloofsuitoefening is nie net sosiaal destruktief nie, maar buite die bereik van sinvolle regsordening: geloof of ongeloof kan nie regtens verorden word nie. Eweneens is religieuse voorskriftelikheid aan die staat teenproduktief, veral in die toenemend algemene situasie van godsdienspluraliteit onder die burgery. Godsdiens is eksklusief; gevolglik kan regsvoorskrifte wat ooreenkomstig een religieuse oortuiging verorden word, potensieel aanstoot aan al die ander gee, en dit sal waarskynlik ook.

Wat staan die hedendaagse staat nou te doen met sy noodsaaklike grondwetlike en regsregulering van die gemeenskap?

\section{Die liberaal-demokratiese respons: Sekularisme}

Oor die aanname dat moderne demokrasieë sekulêr behoort te wees, skryf die Kanadese politieke en sosiale filosoof Charles Taylor (2009:xi-xxii) dat soveel betekenisse aan hierdie begrip geheg word dat daar groot verwarring daaroor bestaan. Hy identifiseer twee breë modelle van staatsekularisme - die een op loutere rasionalisme gebou en wat die volgende beginsels voorstaan:

- vryheid: niemand moet aan religieuse dwang onderwerp word nie;

- gelykheid: geen geloof of Weltanschauung mag 'n bevoorregte status geniet nie;

- broederskap: daar behoort na alle geestelike 'families' geluister te word; en

- harmonie tussen die aanhangers van verskillende lewensbeskouings moet gehandhaaf word.

Die ander model wat Taylor (2009:xvi) identifiseer, berus op demokratiese onderhandeling: '... [t]he actual principles are what we can come to agree on, as something we can all justify from our own point of view'. Hy dui ook tereg aan dat die wortels van sekularisme in die Latynse Christendom lê as die gevolg van die onderskeid tussen profane en hoër tyd, en tussen die geestelike en die tydelike, met die kerk wat eersgenoemde en die staat laasgenoemde beheers het. Die Reformasie het 'n proses tot gevolg gehad waardeur die beheer van verskeie funksies en instellings van die Kerk na die staat oorgedra is. Sekularisering is daardeur in die hand gewerk ten spyte daarvan dat die skeiding van die tydelike en die geestelike ' $n$ Katolieke siening was. Algaande het die idee ontwikkel dat die sekulêre dimensie, dit wat in die waarneembare, profane tyd bestaan, al is wat daar is. Die geestelike dimensie is nie reëel nie; dus het dit nie aanspraak op enigiets wat inbreuk kan maak op die werklike belange van die staatsowerheid en die stoflike welsyn van die mense nie. Sodoende het die siening in die Westerse staats- en regsdenke ontstaan dat dit wat fiktief (spesifiek die religieuse) onwerklik en oorbodig is 
en nie toegelaat mag word om met die realiteit van die daaglikse lewe in te meng nie.

Gedurende die ontstaanstyd van die liberalisme wat met die Reformasie gepaard gegaan het, is sekularisme in die Westerse denke gevestig en word dit steeds gevind in die hedendaagse liberaal-demokratiese denke (miskien heel ironies) op sterkte van verdraagsaamheid teenoor godsdiensverskeidenheid wat veral agnostisisme en ateïsme insluit.

\section{Die aanbreek van die post-sekulêre samelewing}

Daar is aanduidings dat daar in die jongste tyd 'n eskalerende bewustheid in die wêreld is van die belangrikheid van religie. Dit is moeilik om dit te verklaar, maar 'n waarskynlike oorsaak is die groter mobiliteit van 'n globale gemeenskap waarvan die aantal mense oor die afgelope 70 jaar nagenoeg verdriedubbel het. Die situasie het onvermydelik tot 'n verhoogde mate van godsdienspluraliteit in feitlik alle lande gelei. Die prominente Duitse filosoof, Jürgen Habermas, wat sterk klem lê op individuele outonomie, het die term postsekulêre gemeenskap gepopulariseer (vgl. De Been \& Taekema 2012:2). In 2001 het Habermas die standpunt ingeneem dat die sekulariseringshipotese nie meer gebruik kon word om die sosiale werklikheid te verduidelik nie en dat, hoewel geloof en kennis deurlopend teenoor mekaar opgestel staan, geloof ' $n$ waardevolle morele hulpbron is (Reder \& Schmidt 2010:3-7). Na aanleiding van hierdie stelling kan gesê word dat hy die behoefte gevoel het om die Liberalisme se etiese en morele onvrugbaarheid te genees.

Die rol van godsdiens in die een-en-twintigste-eeuse samelewing word natuurlik ook vergroot deur faktore soos die oplewing van radikale Islamisme, die oopstelling van die Sowjetblok, wat die herlewing van kerke in veral Sentraal- en Oos-Europa in die hand gewerk het, die opkoms van kapitalisme in China en die demokratisering van Afrika. Feitlik in elke staat ontstaan daar toenemend punte van wrywing weens godsdiensverskille. Dit word gemanifesteer in kwessies soos kleredrag en persoonlike versiering, voedselvoorskrifte, godsdienstige vakansiedae, besnydenis, huwelike en begrafnisse, en openbare klank soos gebedsoproepe en die lui van kerkklokke. 'n Besondere brandpunt is die kwessie van godsdiens in die onderwys.

Die een-en-twintigste-eeuse staat, as produk van die liberaaldemokratiese denke van die afgelope vier eeue, word gevolglik toenemend met die onmoontlikheid gekonfronteer om agter ' $n$ skans van sekularisme te skuil asof dít hom van sy juridiese verantwoordelikhede kan vrywaar om gemeenskapsorde en geregtigheid te handhaaf

\section{Godsdiens in die regspraak}

Die aanbreek van die grondwetlike era in Suid-Afrika het, soos te wagte kon wees in 'n land met 'n veelfasettige godsdienspatroon, meegebring dat die howe verskeie kere uitspraak moes lewer oor godsdiensverwante kwessies. Uit die aard van die saak moes dit geskied met verwysing na die Grondwet wat volgens die liberaal-demokratiese patroon ontwerp is, maar wat ook belangrike akkommoderende elemente aangaande godsdiens en kultuur bevat. Die resultaat is anders as wat in grondwetlike eweknieë soos Duitsland en Kanada voorkom, maar tot dusver kan geen klinkklare patroon in die uitsprake gevind word waarvan 'n gevestigde benadering afgelei kan word nie. Inteendeel, dit wil voorkom of die samestelling van die regbank en die persoonlike benadering van die regter(s) wat 'n spesifieke uitspraak skryf, 'n sterk invloed op die benadering in elke saak uitoefen. Om 'n indruk van die omvang van die problematiek te kry, is dit nuttig om kortliks te verwys na die wyse waarop howe in Kanada, Duitsland en Suid-Afrika met godsdiens omgaan. ${ }^{5}$

\section{Etiekonderrig in Kanadese skole}

In 2012 het die Kanadese Supreme Court (S.L. and D.J. v Commission scolaire des Chênes and Attorney General of Quebec 2012 SCC 7 (Canada 2012) uitspraak gelewer in 'n saak wat oor Katolieke ouers gehandel het wat onsuksesvol aansoek gedoen het om hulle kinders van 'n staatsvoorgeskrewe kursus 'Ethics and Religious Culture' (ERC) te laat vrystel. Die amptelike doel van die kursus, soos weergegee in die uitspraak, is om 'n begrip vir etiese kwessies by leerders te ontwikkel. Dit moet hulle in staat te stel om oordeelkundige keuses te maak wat gebaseer is op kennis van die waardes en verwysingsraamwerke wat in die gemeenskap bestaan. Die voorgeskrewe onderrig in godsdienskultuur is gemik op die volgende:

\begin{abstract}
... fostering an understanding of several religious traditions whose influence has been felt and is still felt in our society today. In this regard, emphasis will be placed on Québec's religious heritage. The historical and cultural importance of Catholicism and Protestantism will be given particular prominence. The goal is neither to accompany students in a spiritual quest, nor to present the history of doctrines and religions, nor to promote some new common religious doctrine aimed at replacing specific beliefs. (Canada 2012: par. 34)
\end{abstract}

Die aansoek van die ouers voor die hof het voortgevloei uit die vrees dat hulle kinders ernstig benadeel sou word deur blootstelling aan 'the philosophical trend advocated by the state, namely relativism' (Canada 2012: par. 28).

Uiteindelik, nadat die saak deur die howehiërargie gevoer is, het die nege regters van die hoogste hof in Kanada eenparig beslis dat die ouers nie daarin geslaag het om objektief te bewys dat die blootstelling van hulle kinders aan ERC met hulle vermoë om hulle geloof aan hulle kinders oor te dra, sou inmeng nie. Besonder insiggewend vir begrip van die benadering van die hof tot sake rakende godsdiens oor die algemeen, is die volgende dictum (Canada 2012):

The place of religion in civil society has been a source of public debate since the dawn of civilization. The gradual separation of 5.Uit die aard van die saak kan hier net van enkele verteenwoordigende gevalle melding gemaak word. 
church and state in Canada has been part of a broad movement to secularize public institutions in the Western World ... Religious neutrality is now seen by many Western states as a legitimate means of creating a free space in which citizens of various beliefs can exercise their individual rights. (par. 10)

\section{Swemklasse in Duitsland}

In 2013 het die Duitse Federale Administratiewe Hof in BVerwG 6 C 25.12, 11.9.2013, paragrawe 12, 15 en 30 (Duitsland 2012) oor ' $n$ saak beslis waarin 'n Moslem-skoolmeisie deur haar skool toestemming geweier is om van verpligte swemklasse vrygestel te word. Die godsdienstige beswaar was daarop gebaseer dat dogters sowel as seuns aan die swemklasse deelgeneem het en dat dit in stryd was met die beswaarde se geloofsoortuigings rakende fisiese kontak met en blootstelling van die vroulike vorm aan die teenoorgestelde geslag. In die Duitse stelsel beskik die staat oor die reg (Bestimmungsrecht) om die inhoud van skoolonderrig te bepaal enswemklasseisbyverpligteliggaamlike-opvoedingskursusse ingesluit. In hierdie geval was die skool se weiering om die meisie van die swemklasse vry te stel daarop gebaseer dat die skool aan haar toestemming gegee het om tydens die swemklasse ' $n$ 'burkini' te dra. Die burkini is 'n swempak wat ontwerp is om alle liggaamsdele behalwe die gesig, hande en voete van die draer te verberg. Die doel daarvan is om Moslemvroue toe te laat om in die openbaar te swem sonder om hulle liggaamsvorm, selfs in die water, ten toon te stel.

Die hof het beslis dat die skool se optrede geregverdig was, aangesien die toelating van die burkini, wat aan die betrokke godsdienstige vereistes voldoen het, nie op die meisie se godsdiensvryheid inbreuk gemaak het nie. Wat die hof regtens teen mekaar moes opweeg, was die staat se Bestimmungsrecht in die onderwys en die reg op godsdiensvryheid wat regtens gelykwaardig geag word. Die beslissingsmeganisme wat die hof gebruik het, word praktische Konkordanz genoem wat inhou dat mededingende aansprake op verskillende regte op so 'n manier besleg moet word dat soveel moontlik van die aansprake wat uit elkeen voortspruit, gerealiseer kan word. Die hof het daarop gewys dat die vereiste van staatsneutraliteit in die onderrig weliswaar staatsindoktrinasie verbied, maar nie van die skole verwag om die godsdienstige reëls van almal in 'n skool te akkommodeer nie. In die betrokke geval is daar in ag geneem dat die skool in die Duitse samelewing, wat deur pluralisme en individualisme gekenmerk word, gefunksioneer het. Daar kon nie van die skool verwag word om skoolgangers teen blootstelling aan die heersende sosiale gebruike soos die skamele kleredragstyle by openbare swemplekke te beskut nie.

\section{Lyfstraf in Suid-Afrikaanse privaatskole}

In 2000 het die Suid-Afrikaanse Konstitusionele Hof uitspraak gelewer in die saak Christian Education South Africa $v$ Minister of Education (Republic of South Africa 2000) wat oor die vraag gehandel het of 'n statutêre verbod op lyfstraf in skole inbreuk maak op die regte van die ouers van kinders in onafhanklike skole wat ooreenkomstig hulle Christelike geloofsoortuigings tot die toepassing van lyfstraf in die skool ingestem het. Die saak is voor die howe gebring namens 'n vereniging genaamd Christian Education South Africa (met Evangelistiese wortels in die VSA) onder wie se vaandel 196 skole bedryf is. Die eenparige uitspraak van die Konstitusionele Hof is deur Regter Albie Sachs, wat dikwels in die openbaar 'bely' het dat hy 'n agnostikus is, gelewer. Die regter se persoonlike ingesteldheid teenoor geloof en godsdiens, naamlik dat hy intens in die verskynsel belang gestel het maar die relevansie daarvan vir sy persoon afgewys het, kan nie sonder meer as die hof se regverdiging van die uitspraak voorgehou word nie. Die rede daarvoor is dat die uitspraak uiteraard op die vertolking van die toepaslike bepalings van die Grondwet berus het. Verder het die ander lede van die regbank nie wesenlik van die uitspraak verskil het nie.

'n Aspek van die uitspraak wat egter dikwels 'n aanduiding van die persoonlike ingesteldheid van ' $n$ regter is, is die bewoording daarvan waaruit nie net die vertolking, verstaan en toepassing van die reg nie, maar ook persoonlike voorkeure blyk. Vir die doeleindes van hierdie bespreking is dit nodig om dele van die uitspraak woordeliks weer te gee. Regter Sachs (Republic of South Africa 2000) spreek hom soos volg uit:

$[R]$ eligious and secular activities are, for purposes of balancing, frequently as difficult to disentangle from a conceptual point of view as they are to separate in day to day practice. While certain aspects may clearly be said to belong to the citizen's Caesar and others to the believer's God, there is a vast area of overlap and interpenetration between the two. It is in this area that balancing becomes doubly difficult, first because of the problems of weighing considerations of faith against those of reason, and secondly because of the problems of separating out what aspects of an activity are religious and protected by the Bill of Rights and what are secular and open to regulation in the ordinary way. (par. 34)

Hier word erkenning aan die onvermydelike oorvleueling van die geldingsgebiede van die reg en geloof verleen, maar op tipies liberale wyse soos dikwels ook uit die benadering van agnostici en ateïste blyk. Dit kom daarop neer dat godsdiens en geloof op 'n oorvereenvoudigde manier onder die irrasionele geklassifiseer word en dan met die redelikheid van die reg gekontrasteer word. Weliswaar is die geloofsoortuigings van alle mense, ook van agnostici, op die onbewysbare gefundeer, maar om geloof sonder meer as irrasioneel te etiketteer, is onhoudbaar. Daardeur word daar geïgnoreer dat diepad watna onbewysbaregeloofsoortuigings lei, sonder uitsondering déúr beredenering, rasionalisering, die aanvaarding van bewese of veronderstelde, historiese en hedendaagse gegewens kronkel. Op die keper beskou kan redelikheid teenoor irrasionele aannames nie as die essensie van die onderskeid tussen reg en geloof gesien word nie. Hoewel regstoepassing gewoonlik deur sistematiese beredenering gekenmerk word, is die grondslag daarvan ook te vinde in voorveronderstelde en onbewysbare konsepte soos onder andere geregtigheid, billikheid, respek vir menswaardigheid en gelykberegtiging. Hierdie soort beginsels, waardes en riglyne, of hoe die gebruikers daarvan dit ook al wil sien, word uit verskillende lewensbeskoulike, 
soms implisiete, maar meermale ook eksplisiete religieuse vertrekpunte ontleed en geregverdig. Regspraak wat op hierdie en soortgelyke konsepte gebaseer is, berus dus, soos geloof, uiteindelik ook op irrasionele voorkeure en onbewysbare aannames.

Op 'n ander plek in die Christian Education-uitspraak (Republic of South Africa 2000) behandel Regter Sachs die oorvleueling van die reg wat algemeen vir die openbare lewe geld, en geloof wat in die liberale denke in die privaatsfeer hoort, al het dit ook openbare verskyningsvorms. Die hof moet ' $n$ manier vind om die mededingende belange van hierdie twee geheel en al verskillende konseptuele en eksistensiële ordes te balanseer. Die volgende insig kom dan na vore (Republic of South Africa 2000):

However religion is not always merely a matter of private individual conscience or communal sectarian ${ }^{6}$ practice. ... They are part of the fabric of public life, and constitute active elements of the diverse and pluralistic nation contemplated by the Constitution. Religion is not just a question of belief or doctrine. It is part of a way of life, of a people's temper and culture. (par. 33)

Weens die openbare manifestering van godsdiensbeoefening en geloofsoortuiging kan die reg dit dus nie ignoreer nie (Republic of South Africa 2000):

The underlying problem in any open and democratic society based on human dignity, equality and freedom in which conscientious and religious freedom has to be regarded with appropriate seriousness, is how far such democracy can and must go in allowing members of religious communities to define for themselves which laws they will obey and which not. Such a society can cohere only if all its participants accept that certain basic norms and standards are binding. (par. 35)

Hierdie insig van die hof weerspreek die siening dat die reg en geloof niks met mekaar te doen het nie. Dit is 'n ware dilemma vir die liberale denker. Deur die eeue kon reg en geloof nie hermeties van mekaar geskei word nie. Die liberale gedagte dat die reduksie van geloof tot die privaatsfeer kenmerkend is van ' $n$ ontwikkelde of gearriveerde samelewing wat geskille met koue redelikheid besleg, is nie redelik verdedigbaar nie. Die werklikheid is egter dat dit steeds die heersende denkraamwerk van Westerse konstitusionalisme is en die globale staatsregtelike terminologie bepaal.

Wanneer geloofkeuses met regsvoorskrifte bots, is logika onvoldoende om die kwessies te besleg. In die Christian Education-saak (Republic of South Africa 2000) het die hof ' $n$ morele keuse gemaak deur die Grondwet so te vertolk dat diebeskerming van'n bepaalde siening van menswaardigheid en liggaamlike integriteit voorkeur moes kry bo die geloofsoortuigings van die betrokke skoolgemeenskap. Dit is nie duidelik op watter grondslag hierdie morele keuse gemaak is nie. Die reg, in hierdie geval 'n grondwet waarin liberaal-demokratiese konsepte weerspieël word, moet natuurlik deur die howe vertolk word. Die interpretasie hou

6.Die waardegelade woordkeuse (sectarian) is insiggewend. Die regter implisee daarmee dat openbare geloofhandelinge en -gebruike van die agnostiese (liberale) sosiale norm afwyk en vooroordeel, onverdraagsaamheid en die moontlikheid van onlogiese fanatisme inhou. meer in as matematiese berekeninge met rigied voorspelbare resultate. Die opregtheid van die applikante se oortuigings rakende lyfstraf word nie deur die hof in twyfel getrek nie, maar daar word teen hulle bevind op sterkte daarvan dat die bevestiging van die geldigheid van die statutêre verbod op lyfstraf hulle nie verplig 'to make an absolute and strenuous choice between obeying a law of the land or following their conscience' nie (Republic of South Africa 2000: par. 51).

Die uitkoms van die Konstitusionele Hof se beslissing, naamlik dat die handhawing van die statutêre beletsel dat onderwysers kinders in die skool met lyfstraf mag dissiplineer, is nie noodwendig verkeerd nie, hoewel daar beslis ruimte vir uiteenlopende opinies daaroor is. Vir die doeleindes van hierdie bydrae demonstreer die uitspraak egter ' $n$ bepaalde interpretasiebenadering, naamlik die heersende liberaal-Westerse voorkeur vir staatsekularisme, sonder dat dit as sodanig deur die Hof uitgespel is.

\section{Neusversiering in Suid-Afrikaanse skole}

Die Suid-Afrikaanse reg gaan anders om met die verband tussen reg en godsdiens as die regsordes van ander lande wat met liberaal-demokratiese grondwette werk. Insiggewend in hierdie verband is die uitspraak in 2007 van MEC for Education, KZN v Pillay (Republic of South Africa 2008) deur die Konstitusionele Hof oor 'n staatskool se weiering dat 'n Hindoe-skoolmeisie 'n kraletjie aan haar neusvleuel dra. Volgens die Hindoe-familiekultuur begin ' $n$ jongmeisie die neuskraletiie dra wanneer sy die ouderdom van hubaarheid bereik. Die vraag was of die skool se weiering om 'n uitsondering op die skooldragreëls te maak op ongrondwetlike diskriminasie neergekom het. Die Hof het bevind dat die onbuigsaamheid van die skoolreëls grondwetlik ongeregverdig is omdat dit diskriminerend is om sekere juwele soos kraletjies aan geperforeerde oorlobbe ooreenkomstig die algemene mode toe te laat, maar die kultureel-godsdienstige simbool van die neuskraletjie te weier.

Die manier waarop die Hof in hierdie saak met godsdiens en kultuur omgegaan het, demonstreer 'n gebalanseerde vertolking van die diskriminasieverbod van artikel 9 van die Grondwet, wat onder meer op godsdiens en kultuur betrekking het, en die toepassing van artikel 15 wat die vryheid van gewete, godsdiens, denke, geloof en opinie as fundamentele reg waarborg. Die balans wat die Hof by monde van hoofregter Langa gevind het, het betrekking daarop dat die skool as staatsinstelling verplig is om individuele fundamentele regte in die plurale SuidAfrikaanse samelewing te respekteer, te beskerm, te bevorder en te verwesenlik (artikel 7[2] van die Grondwet). Ter verdediging van die kleredragreëls het die skool onder meer geargumenteer dat die neuskraaltjie 'n populêre mode-item geword het. 'n Uitsondering vir die applikant sou, volgens die skool, baie ander skoolgangers wat nie haar geloofsoortuigings of kultuur deel nie, toelaat om die uitsondering te misbruik. Die Hof het hierdie argument verwerp omdat dit nie die applikant se geloofsoortuiging respekteer het nie en dat dit daarop neergekom het dat groter beskerming verleen sou word aan godsdienste en kulture 
waarvan die simbole goed bekend is, terwyl hulle selde beskerming nodig het. Die Hof verwerp hierdie argument (Republic of South Africa 2008):

It would also have the absurd result that if a turban, yarmulke or headscarf became part of popular fashion they would no longer be constitutionally protected, while they have constitutional protection as long as they remain on the fringes of society. (par. 160)

Dit kan interessant wees om te oorweeg wat die uitkoms van die Pillay-saak (Republic of South Africa 2008) sou gewees het as die beredeneringswyse wat in die Christian Educationsaak (Republic of South Africa 2000) gebruik is, ook daarop toegepas is en andersom. Die Hof kon in die Christian Education-saak (Republic of South Africa 2000) bevind het dat die ouers se oortuiging van die wenslikheid van lyfstrafdissipline op geloofsgronde sterk genoeg was dat die uitsondering binne redelike perke grondwetlik toelaatbaar behoort te wees. Die Pillay-uitspraak (Republic of South Africa 2008) kon gefundeer word op die veroorlowing van die beperkende skoolvoorskrifte op sterkte daarvan dat skooldissipline swaarder behoort te weeg as 'n niedwingende godsdienstig-kulturele gebruik.

Nietemin, uit die voorafgaande bespreking is dit duidelik dat die raakpunte en oorvleuelingsterreine van godsdiens en reg nie weggeredeneer kan word nie. Vanselfsprekend sal sake oor blatante diskriminasie 'makliker' besleg kan word. Voorbeelde is die belediging of verkleinering van ander se geloof en waar een godsdienstige instelling staatsubsidie ontvang, terwyl soortgelyke instellings van ander godsdiensgroepe geen ondersteuning geniet nie.

Sake waarin aangeleenthede wat eksplisiet deur die Grondwet toegelaat word ter sprake kom, behoort ook nie vir die howe ' $n$ besondere uitdaging te wees nie. ' $n$ Voorbeeld is godsdiensbeoefening in skole op ' $n$ billike en vrywillige grondslag ooreenkomstig artikel 15(2) van die Grondwet. Indien ' $n$ hof egter in stryd met die strekking van die Grondwet sekulêre staatsneutraliteit in die beregting van sulke sake probeer invoer, sal dit tot onreg lei. Die rede is dat religieuse voorkeur daardeur aan liberale sekularisme gegee sal word ten koste van die ander betrokke godsdienste.

\section{Sekulêre staatsneutraliteit geweeg}

Hierbo is nie van die grondwetlike benadering tot godsdiens in die VSA melding gemaak nie. Daarvoor is daar ' $n$ goeie rede. Dit is nie 'n tersaaklike voorbeeld nie, aangesien die Suid-Afrikaanse grondwetteks 'n keuse weerspieël wat doelbewus anders is. Die VSA se grondwet is aan die einde van die agtiende eeu geformuleer, toe die klassieke liberalisme hoogty gevier het as die voorste, revolusionêre denke van die tyd. In die Amerikaanse grondwetlike dogma is daar sprake van ' $n$ 'wall of separation' tussen staat en kerk en mettertyd het dit so ingeburger geraak veral deur die regspraak, dat die volgende frase uit 'n toespraak van John Quincy Adams (die sesde President van die VSA) in 1839 vandag nog in die Amerikaanse staatspsige gereflekteer word (aangehaal deur House 1999):
Fellow-citizens, the ark of your covenant is the Declaration of Independence. Your Mount Ebal, is the confederacy of separate state sovereignties, and your Mount Gerizim is the Constitution of the United States. (p. 204)

Die konsep van 'n grondwet-gebaseerde civil religion leef steeds in die VSA. ${ }^{7}$ Dit geld nie in Suid-Afrika nie. Hoofregter Chaskalson het in die eerste saak waarin godsdiens voor die Konstitusionele Hof ter sprake gekom het, die Amerikaanse grondwetlike verbod op die establishment van godsdiens (religion) van die Suid-Afrikaanse benadering eksplisiet onderskei ( $S v$ Lawrence; $S$ v Negal; $S v$ Solberg - Republic of South Africa 1997b):

Our Constitution deals with issues of religion differently to the US Constitution. It does so under the equality provisions of section 8 , the freedom of religion, belief and opinion provisions of section 14 , and the education provisions of section 32. (par. 100) ${ }^{8}$

Nogtans, soos soms uit die bewoording van hofuitsprake in Suid-Afrikaanse howe blyk, is die gebruik van sekulêre taal moeilik om te weerstaan in die toepassing van die Grondwet wat andersins sterk op liberaal-demokratiese konsepte steun.

Stefan Huster (2002) se (Duitse) perspektief op liberale sekularisme as 'n karaktereienskap van hedendaagse politieke ordes is dat daar 'n verpligting op hulle rus om hulle teenoor almal te regverdig. Slegs die instemming van almal wat aan die regsorde onderworpe is en nie tradisie, geskiedenis of 'n beroep op die wil van God nie, gee die deurslag. Die staat moet dus afstand doen van alle spesifieke religiös-weltanschauliche regverdigings.

Denise Meyerson (2009), voorheen 'n Suid-Afrikaner en tans 'n Australiër, is 'n liberalistiese regsfilosoof. Drie beginsels van openbare moraliteit wat heelwaarskynlik veronderstel is om universeel van toepassing te wees, word deur haar voorgehou: 'n regering se optrede mag nie godsdienstige doelwitte nastreef nie; dit mag nie godsdiensgroepe ondersteun om hulle oortuigings te versprei nie; en argumente wat slegs op godsdienstige oortuigings gebaseer is, kan nie voorgehou word om wette en openbare beleid te regverdig nie.

Maurice Adams van Tilburg, Nederland, kritiseer Meyerson se siening, wat op die werk van die liberale Amerikaanse regsfilosoof John Rawls gebaseer is, dat die staat ooreenkomstig oorvleuelende gemeenskapskonsensus regeer behoort te word, spesifiek sonder enige verwysing na geloofsoortuigings oor wat goed is. Adams (2009:22) se kommentaar kan soos volg opgesom word: Die beoordeling van wat goed is, geskied uit die aard van die saak vanuit ' $n$ persoonlike perspektief oor wat goed en sleg is. Indien dit nie waar is nie, het 'n mens niks waarop die beoordeling gebaseer kan word nie. Beoordeling van goed en sleg kan nie sonder verwysing na 'n persoonlike, onvermydelik religieus-morele

7.Davis (2011) beskryf dit soos volg: The Pledge of Allegiance is our creed, the Constitution is our scripture and our founding fathers are our patriarchs. We are devoted to democracy, we pray for our progress, and we are committed capitalists. devoted to democracy, we pray for our progress, and we are committed capitalists. Our prisons are our civil religion's purgatory, where we hope the crimina perpetrators prove penitent. We celebrate our saintly soldiers on Memorial Day, and
we praise our political prophets such as Martin Luther King, Jr. (p. 97)

8.Die artikelverwysings in hierdie uitspraak het nog na dié van die oorgangsgrondwet van 1993 verwys, maar dit stem ooreen met die ooreenstemmende bepalings van die 1996-Grondwet. 
denkraamwerk plaasvind nie. So swig die liberale benadering onder die druk van sy eie logika, aldus Adams.

Die ooglopende leemte in liberale denke oor staat en godsdiens is die onoortuigende poging om etiek en moraliteit te relativeer of uit te skakel. Herman Dooyeweerd (2012) het dit knap soos volg saamgevat:

Philosophy is theoretical, and in its constitution it remains bound to the relativity of all human thought. As such, philosophy itself needs an absolute starting point. It derives this exclusively from religion. Religion grants stability and anchorage even to theoretical thought. Those who think they find an absolute starting point in theoretical thought itself come to this belief through an essentially religious drive. Because of a lack of true self-knowledge, however, they remain oblivious to their own religious motivation. (p. 8)

\section{Neutraliteit is onmoontlik}

Die liberale eis dat die gesag van die staat, hetsy in wetgewende, uitvoerende of regsprekende hoedanigheid neutraal uitgeoefen moet word, veronderstel dat neutraliteit moontlik is. Om neutraal te wees, beteken om onbetrokke, ongeïnteresseerd, afsydig en belangeloos te wees: wiskundig uitgedruk nie +1 of -1 nie, maar 0 . 'n Staatsowerheid kan nie neutraal wees nie, want dan sou dit passief in die staatsgemeenskap moet wees. Die uitoefening van staatsgesag wat daargestel word om maatskaplike orde tot stand te bring en te handhaaf, gaan gepaard met die neem van besluite en dus om keuses te maak. So kan ' $n$ hof byvoorbeeld nie neutraal staan teenoor die sake van gedingspartye waaroor daar bereg moet word nie, want dit sou beteken dat die hof geen belangstelling in die balansering van die aansprake en belange waaroor daar uitspraak gelewer moet word, mag hê nie. Verder is dit ook menslik onmoontlik vir regters en ander gesagsdraers om soos rekenaars of robotte te funksioneer. Faktore soos onder andere gesonde oordeel, regverdigheid, empatie, openbare belang en geregtigheid moet ' $n$ rol speel, anders kan daar nie van 'n verdedigbare beoordeling sake sprake wees nie. Sulke faktore is nie kleurloos neutraal nie. Omdat hulle uit fundamenteel religieuse oortuigings voortspruit, kan hulle intense emosies ontlok.

Natuurlik beteken dit nie dat die uitoefening van owerheidsgesag bevooroordeeld uitgeoefen mag word nie. Die beginsel geld veral ook vir regspraak, en in besonder vir regspraak waarin godsdienskwessies ter sprake kom. Wat vir die gebalanseerde gesagsdraer nodig is, is eerlike selfkennis. Hy of sy moet in staat wees om te erken dat dit vir 'n mens onmoontlik is om jou van jou grondoortuigings, dit wil sê jou geloofoortuigings los te maak. Dit is ook waar vir die agnostiese verwerping van godsdiens of liberale vertroue op die menslike rede. Sulke selfkennis maak die objektiewe uitoefening van gesag moontlik.

In teenstelling met emosielose neutraliteit is objektiwiteit 'n bewuste keuse, naamlik om, met inagneming van 'n mens se onvermoë om jou voorkeure en vooroordele volkome uit te skakel, die bes moontlike, billikste en regverdigste uitkoms in die betrokke omstandighede te bereik.
Van die gesagshandelinge van politici in 'n mededingende veelpartydemokrasie kan objektiwiteit nie verwag word nie, want kenmerkend van politieke beleid is die selektiewe bevordering van seksionele belange. Die uitvoerende handelinge van staatsamptenare val egter in 'n ander kategorie. Artikel 195(1)(d) van die Grondwet vereis dat die dienste van die openbare administrasie 'moet onpartydig, regverdig, op billike grondslag en sonder vooroordeel gelewer word'. Wat die regsprekende gesag betref, vereis artikel 165(2) dat die howe onafhanklik en slegs aan die Grondwet en die reg onderworpe, onpartydig en sonder vrees, begunstiging of vooroordeel moet regspreek.

Dit is hieruit duidelik dat daar in die Grondwet geen sprake van neutraliteit is nie, maar van objektiwiteit. Dat objektiewe staatsadministrasie en regspraak gewens is, is nie afhanklik van die bepalings van die Grondwet nie. Bepalings van die Grondwet wat objektiwiteit in die hand werk, weerspieël 'n universeel geldige beginsel wat deur Skrifgelowiges verstaan word as 'n skeppingsgegewe. Dit is 'n beginsel wat al eeue lank deur die mensdom verstaan word as net so universeel vanselfsprekend soos die beletsel op moord of diefstal.

\section{Wederkerigheid}

Die beginsel van wederkerigheid (reciprocity) kom al deur die eeue heen voor in die leerstellings van uiteenlopende godsdienste en filosofieë waaronder die Konfusianisme, Judaïsme, Hindoeïsme en die Christendom. Hoewel dit nie op dieselfde wyse gemotiveer of verduidelik word nie, is die kern daarvan nog altyd dieselfde 'goue reël' (sien bv. Wattles 1996). Die oudste literatuur waarin dit gevind word, is die leerstellings van K'ung-fu-tzu [Konfusius], wat in die vyfde eeu voor Christus geleef het. Dit kom ook voor in verskillende bekende formulerings van Jesus wat in die Evangelies te vinde is: 'Alles wat julle wil hê dat die mense aan julle moet doen, moet julle ook aan hulle doen. Dit is tog waarop dit neerkom in die wet en die profete' (Matt 7:12); 'Jy moet jou naaste lief hê soos jouself' (Mark 12:31); 'Behandel ander mense soos julle self behandel wil word' (Luk 6:31). Die Heidelbergse Kategismus gee die volgende antwoord op vraag 111, wat oor die agste gebod handel: 'Ek moet die belange van my naaste, waar ek kan en mag, bevorder en hom so behandel soos ek wil hê dat hy my moet behandel.'

Die universele wederkerigheidseis maak dit moontlik om objektiwiteit in die uitoefening van gesag na te streef. Die regter wat oor 'n kwessie waarby die godsdiens of geloof van ander mense betrokke is, moet oordeel, kan in so 'n saak geregtigheid laat geskied, ongeag of die geloofsoortuigings en godsdiensgebruike van een of al die partye met sy eie strook al dan nie. Daarvoor is dit egter nodig dat die regter nie in die waan verkeer dat neutraliteit moontlik is nie, maar dat persoonlike geloofs- en lewensbeskoulike vooroordeel uit selfkennis erken moet word. Dit kan hom of haar in staat stel om die tersaaklike kwessies objektief te beoordeel met die oog op die optimale realisering van die wederkerigheidsbeginsel. ${ }^{9}$

9.In Venter (2015:237-240) word in meer besonderhede op objektiewe regspleging ingegaan. 


\section{Erkenning \\ Mededingende belange}

Die outeur verklaar dat hy geen finansiële of persoonlike verbintenis het met enige party wat hom nadelig of voordelig kon beïnvloed het in die skryf van hierdie artikel nie.

\section{Literatuurverwysings}

Adams, L.H.J., 2009, 'Religie in de publieke ruimte: Constitutionele contouren en politieke theorie', in A.J. Nieuwenhuis \& C.M. Zoethout (eds.), Rechtsstaat en religie, pp. 5-29, Wolf Legal Publishers, Nijmegen.

Davis, A.P., 2011, 'International civil religion: Respecting religious diversity while promoting international cooperation', Hastings International and Comparative Law Review 34, 87-126.

De Been, W. \& Taekema, S., 2012, 'Religion in the 21st century: Debating the postsecular turn', Erasmus Law Review 5(1), 1-3.

Dooyeweerd, H., 2012 [1959], 'Roots of Western culture: Pagan, secular, and Christian options', in D.F.M. Strauss (ed.), The collected works of Herman Dooyeweerd, transl. and ed. J. Kraay, Paideia Press, Grand Rapids. (The collected works of Herman Dooyeweerd, ser. B, 15).

House, H.W., 1999, 'A tale of two kingdoms: Can there be peaceful coexistence of religion within the secular state?', Brigham Young University Journal of Public Law $13,203-292$.

Huster, S., 2002, Die ethische Neutralität des Staates: Eine liberale Interpretation der Verfassung, Mohr Siebeck, Tübingen.

Meyerson, D., 2009, 'Why religion belongs in the private sphere, not the public square', in P. Cane, C. Evans \& Z. Robinson (eds.), Law and religion in theoretical and historical context, pp. 44-71, Cambridge University Press.
Reder, M. \& Schmidt, J., 2010, 'Habermas and Religion', in J. Habermas et al. (eds.) An awareness of what is missing: Faith and reason in a post-secular age, transl. C. Cronin, pp. 3-7, Polity Press, Cambridge.

Republiek van Suid-Afrika, 1993, Grondwet van die Republiek van Suid-Afrika, 200 van 1993, Staatsdrukker, Pretoria.

Republiek of Suid-Afrika, 1996, Grondwet van die Republiek van Suid-Afrika, Staatsdrukker, Pretoria

Taylor, C., 2009, 'Foreword: What is secularism?', in G.B. Levey \& T. Modood (eds.), Secularism, religion and multicultural citizenship, pp. xi-xxii, Cambridge University Press, Cambridge.

Venter, F., 2010, 'Liberal Democracy: The unintended consequence - South African Constitution-writing propelled by the winds of globalisation', South African Journal on Human Rights 26, 43-63.

Venter, F., 2015, Constitutionalism and Religion, Edward Elgar, Cheltenham.

Wattles, J., 1996, The golden rule, Oxford University Press, New York.

\section{Hofsake}

Canada, 2012, S.L. and D.J. v Commission scolaire des Chênes and Attorney General of Quebec 2012 SCC 7, S.C.R. 235.

Duitsland, 2012, BVerwG 6 C 25.12, 11.9.2013.

Republic of South Africa, 1997a, In re: Certification of the Constitution of the Western Cape, 1997 (4) SA 795 (KH).

Republic of South Africa, 1997b, S v Lawrence; S v Negal; S v Solberg 1997 (4) SA 1176 (KH).

Republic of South Africa, 2000, Christian Education South Africa v Minister of Education 2000 (4) SA 757 (KH).

Republic of South Africa, 2008, MEC for Education, KZN v Pillay 2008 (1) SA 474 (KH).

United States of America, 1984, Lynch, Mayor of Pawtucket, et al. v Donnelly et al. 465 US 668, 716 (1984). 